\title{
Design of Manufacturing System Layout using Digital Technologies
}

\author{
Martin Krajčovič ${ }^{1, *}$, Miroslav Rakyta ${ }^{1}$ \\ ${ }^{1}$ Department of Industrial Engineering, Faculty of Mechanical Engineering, University of Žilina
}

\begin{abstract}
Current modern technologies as well as classical disciplines of industrial engineering, among which also design of manufacturing and logistics systems can be ranked, have achieved a new dimension. Technologies and concepts as digital factory, reverse engineering, 3D modelling, simulation of manufacturing and logistics systems, transform design into a virtual environment. These progressive technologies enable time reduction, thus also reducing development costs. Digital representation of manufacturing system have a great importance in connection with the development of intelligent factories and application of digital twin concept. This paper presents approach to manufacturing systems design using progressive digital technologies.
\end{abstract}

\section{Introduction}

Nowadays companies must be sufficiently flexible with respect to increasing diversity and changes in customer requirements and needs, so that they can stay competitive in the current dynamic and turbulent environment. The time becomes a key factor, what is reflected in the need for constant shortening of product innovation cycles and consequently in the need for shortening of processes and systems innovation cycles.

The implementation and operation of progressive manufacturing systems requires highly qualified specialists able to design and to apply new methods and technologies based on artificial intelligence and utilization of progressive digital technologies, able to increase the quality, flexibility and efficiency of designed manufacturing systems.

\section{Methodology of Manufacturing System Design using Digital Technologies}

Process of manufacturing systems layout design in virtual environment has to respect the fundamental principles of the manufacturing systems design. With regard to the requirements for increase in the resultant design quality and decrease in the design time, it is necessary to enrich the classical approaches to the manufacturing systems with implementation of new progressive approaches and computer technologies. The process of manufacturing and logistics systems design has to run in the following phases (Fig. 1):

1. Preparation and analysis of input data.

2. Capacity requirements planning.

3. Proposal of ideal spatial arrangement.

4. Design of real manufacturing and logistics system.

5. Dynamic verification of the proposed system using computer simulation.

6. Visualization of the proposed manufacturing and logistics system.

Individual steps and their realisation with the support of progressive computer technologies will be presented in the next part. 


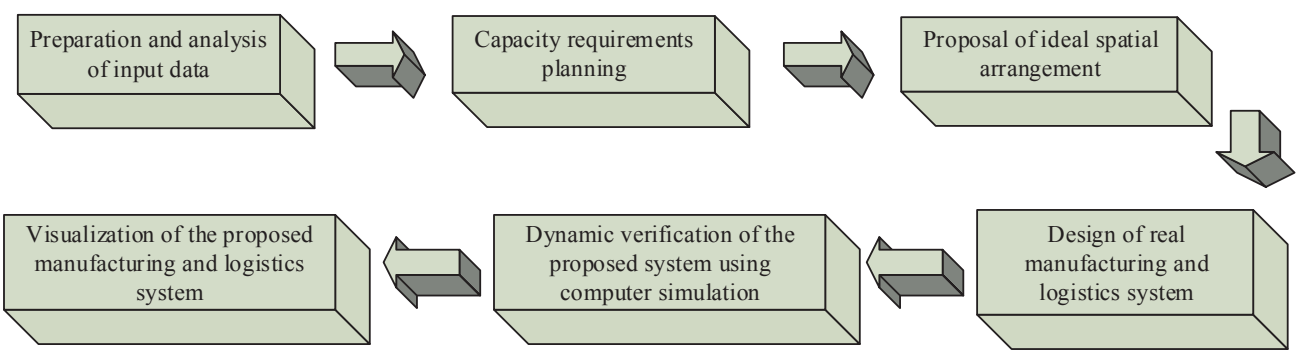

Fig. 1: Methodology of manufacturing system design.

\section{Input Data Preparation and Analysis}

The basis resource of information needed for design is, first of all, the database from construction and technological preparation of production. Data for the manufacturing systems design can be divided into two basic groups: numerical data and graphical data.

In compliance with a digital factory concept, numerical data are structured in three key areas:

- Information about products which will be made and transported in the manufacturing system (product types, piece lists, construction parameters, planned production volumes, etc.),

- Information about processes of their production (operations, manufacturing and assembling processes, used technologies, time norms, etc.),

- Information about resources for their manufacture (manufacturing machines and equipment, tools, workers, transport and handling machines, handling units, storage premises, etc.).

Analysis of numerical input data includes the following areas:

1. Product analysis ( $P Q$ analysis, $P P$ analysis, $P G$ analysis, GT codes, BOM analysis, etc)

2. Analysis of manufacturing processes and material flows (value stream mapping, process maps, sankey chart, D-I chart, from-to diagram, relationships diagram, etc.)

3. Resource analysis

4. Other analyses: auxiliary and control processes, cost analysis, time consumption analysis, human resource analysis, etc.

Design and visualisation of a manufacturing system in a digital environment requires a preparation of 3D models for all components that will make up a proposed system (manufacturing machines and equipment, transport and handling machines, handling units, storage premises, auxiliary premises, etc.). Created digital 3D models then become the fundamental building block of a digital design of manufacturing and logistics systems in a computer environment.

For preparation of 3D models of individual objects of manufacturing and logistics systems, one of the following procedures can be utilised:

- Creation of new models using CAD software (AutoCAD, Microstation, (ATIA, etc.),

- Acquisition of new 3D models using methods of reverse engineering (3D laser scanning),

- Creation and utilisation of 3D parametric models,

- Arrangement of existing CAD models using software tools for modelling, rendering and animation of $3 D$ models.

\section{Capacity Requirements Planning}

Before we start designing spatial solution of a manufacturing system, we have to decide which resources (production machines and equipment, transport, handling and storage devices, handling units, and the like), from the viewpoint of types and number, will be needed to ensure particular manufacturing and logistics processes in a designed system. Capacitance calculations serve this purpose. To calculate capacity needs, the designer has to know individual operations and activities of the manufacturing system, their quantity, time consumption norms for individual operations and available time for individual categories of resources.

From the viewpoint of dimensioning of individual categories of resources in the manufacturing and logistics system there are following capacitance calculations:

- Needs of production machines and equipment, - Needs of transport equipment, handling equipment and handling units,

- Needs of storage devices,

- Needs of other resources (auxiliary equipment, workers, energy, areas).

\section{Proposal of ideal spatial arrangement}

When we know the need of individual resources of the designed system, material flows and other 
connections among individual elements, we can begin with designing an ideal spatial arrangement of the manufacturing or logistics system. In this phase of the proposal, no real spatial requirements of workplaces, no input-output places of the system and any other restrictions are considered (e.g. spatial restrictions).

Proposing an ideal arrangement, it is advantageous to use optimisation methods and algorithms which can be classified as follows:

- Graphical methods (Sankey chart, spaghetti diagram, relationship diagram, etc.),

- Analytical methods (linear and non-linear programming, transport problem, dynamic programming, etc.)

- Heuristic methods: construction procedures (CORELAP, ALDEP, PLANET, MAT, MIP, INLAYT, FLAT, etc.), exchange procedures (CRAFT, MCRAFT, MULTIPLE, H63, FRAD, COFAD, etc.), combined procedures (BLOCPLAN, LOGIC, etc.)

- Metaheuristic methods (genetic algorithms, simulated annealing, tabu search, etc.)

\section{Design of Real Manufacturing and Logistics System}

Further stage of the solution of proposal layout of the manufacturing system is performed exclusively in a software environment. Software environment for creation of real layout enables the designer, in a very short time, to verify more variants of detailed solution of either manufacturing or logistics system for which he uses tools for analysis, assessment and optimisation of the layout from the viewpoint of material flows and logistics. The designer can then make changes in the layout continuously; simultaneously with every change the designer receives the feedback about change of material flow parameters in the system, which enables him interactively and in a very short time to improve spatial arrangement of the designed system.

Currently there are more software solutions and packets to support a 2D/3D design of layout solutions of manufacturing and logistics. The most famous of them are following: visTABLEtouch, Tecnomatix FactoryCAD / FactoryFLOW, Autodesk Factory Design Suite, MALAGA / MASSIMO, MPDS4 Factory Layout, EON Planner, etc.

\section{Dynamic Verification of the Proposed System using Computer Simulation}

The importance of simulation grows mostly with a growing system complexity. Computer simulation is in this case the only tool which allows, also in complex systems, "a view to the future" with high accuracy and expressive power. The simulation application enables industrial factories to save a large sum of money. Great advantage is at present the strong software support for simulation of manufacturing and logistics systems (Arena, Simple++, Witness) and its integration into software solutions of the digital factory concept (DELMIA Quest, Tecnomatix Plant Simulation).

The procedure of computer simulation implemented in conditions of dynamic verification of the proposed manufacturing or logistics system involves the following basic steps:

- Export of data about the designed system from software for the manufacturing systems design,

- Import of data to simulation software environment,

- Arrangement and completion of imported data,

- Verification and validation of the simulation model,

- Making simulation experiments and gathering statistical data,

- Assessment of experiments or a proposal of additional simulation experiments (if results of simulation experiments do not meet expectations put on the system),

- Choice of simulation experiment with the best results, adjustment of corresponding parameters of the system design and introduction to real conditions.

\section{Visualisation of the Proposed Manufacturing and Logistics System}

To meet the needs of a team proposal, visualisation and presentation of a layout plan for the manufacturing or logistics system design, it is appropriate to connect the software for the manufacturing systems design with the hardware platform which enables working with the layout plan not only to an individual worker but to a team of workers. Such hardware solution is embodied in a planning table (Fig. 2).

Visualization of the projected production system in the 2D view on the area of the projection planning table is accompanied by a 3D visualization using augmented reality technologies which add selected virtual elements / objects into the real environment. Technology of the projection planning table is supplemented by AR virtual 3D models of various elements of the production system and the models of workplaces in the 2D layout serve as markers (Fig. 3a). In the final phase AR technology is also used for visualization of the 
production system in the real environment of the production hall (Fig. 3b).

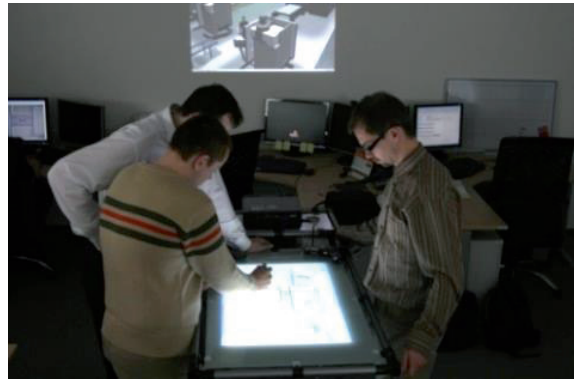

a) Planning table with the bottom projection

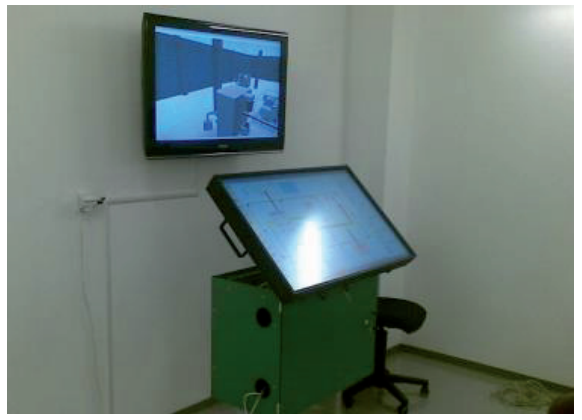

b) Planning table with multi touch display

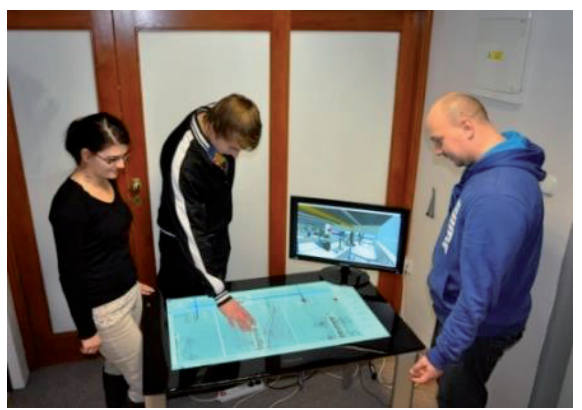

c) Planning table using Samsung Surface platform

Fig. 2: Variants of planning table developed by IED, University of Zilina and CEIT, Zilina.

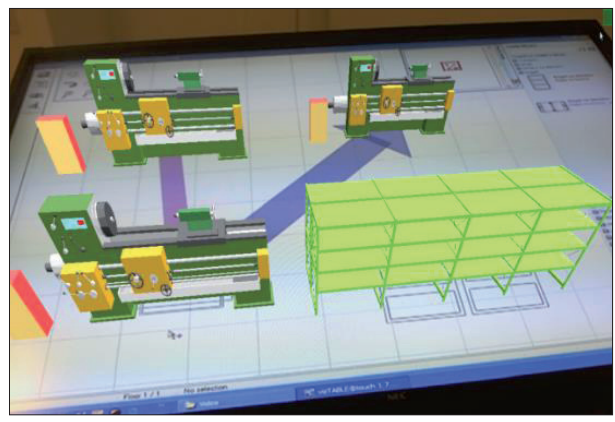

a) Planning table

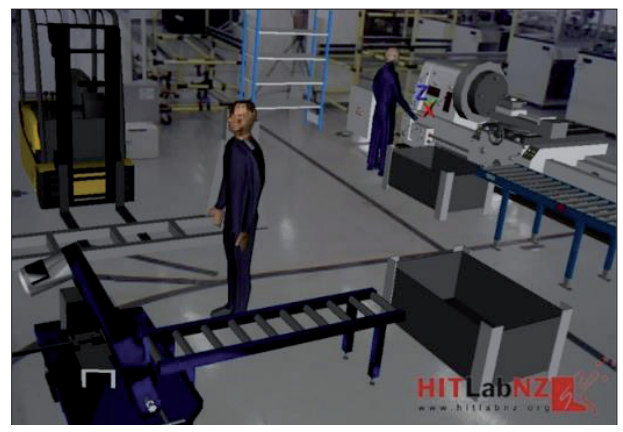

b) Real production hall

Fig. 3: Layout visualization using augmented reality.

\section{Conclusion}

The paper describes design procedures of manufacturing systems using digital technologies. This approach interconnects classical approaches and methods with technological design methods (preparation and analysis of input data, use of optimisation algorithms) with new technologies of digital processing and data visualisation (CAD and graphical software, technologies of reverse engineering, software for layout plans, computer simulation, technologies of augmented reality) into functional methodology of design and visualisation of manufacturing and logistics systems.

The described designing procedure brings:

- Improved interaction between a designer and designed system,

- Reduction of time needed for the proposal of a new system or reconstruction of the existing system,

- Increased quality of the proposal due to dynamic evaluation by computer simulation,

- Cost reduction in a designed manufacturing or logistics system,

- Participation of multidisciplinary team in the problem solution.

Possible applications of progressive digital technologies are objects of further research performed at the Department of Industrial Engineering, University of Zilina, in the framework of development area of "a digital factory".

\section{Acknowledgments}

This paper was supported by research project KEGA 004ŽU4/2016 - Utilization of augmented and virtual reality in education of subjects focused on manufacturing and logistics systems design. 


\section{References and Notes}

[1] BRUNO, F., CARUSO, F., DE NAPOLI, L., MUZZUPAPPA, M.: Visualization of Industrial Engineering Data in Augmented Reality. J. of visualization. ISSN 1343-8875, vol. 9, No. 3, 319329, 2006.

[2] EBBESMEYER, P. et al.: Designing Flexible Production Systems with Virtual Reality. Proceeding of the ASME 2001 Design Engineering Technical Conference on Computers and Information, Pittsburgh, Pennsylvania, 2001.

[3] FURMANN, R., ŠTEFÁNIK, A.: Progressive Solutions Supporting Manufacturing and Logistics Systems Design Developed by CEIT SK, s.r.o. (in Slovak). Produktivita a inovacie, Zilinska univerzita: Ustav konkurencieschopnosti a inovacii, vol. 2, No. 2, 2011, 3-5ISSN 1335-5961.

[4] GABAJ, I. - KRAJČOVIČ, M.: Use of augmented reality in design of production system. In: Industrial engineering of the future - InvEnt 2011: proceedings of the international conference: 19.9.-21.9.2011, Žilina, 2011. ISBN 978-80-554-04097. - S. 20-23.

[5] GRZNÁR, P. - CUDRÁKOVÁ, M. - PEDAN, M. 2016. Simulation of decision-making processes. In: InvEnt 2016 : industrial engineering - toward the smart industry : proceedings of the international conference : 15.6.-17.6.2016, Rožnov pod Radhoštěm, CZ. Žilina: University of Žilina, 2016. ISBN 97880-554-1223-8. S. 56-59.

[6] KRAJČOVIČ, M. 2015. Internal logistics design with the support of digital technologies. In: Chosen applications of computer modelling in mechanical engineering. - London: Pearson Education Limited, 2015. ISBN 978-1-78447-830-8. S. 183-206.

[7] KOVÁČ, J., RUDY, V., KOVÁČ, J.: Automatizácia výroby. 1.vydanie Košice, TU, 2016, Edicia vedeckej a odbornej literatúry. ISBN 978-80-553-2311-4, $304 \mathrm{~s}$.

[8] KOVÁČ, J., RUDY, V., MAREŠ, A., KOVÁČ, J., MALEGA, P.: Integrated designing of production systems on the physicale and virtual modelling base. In. Acta Mechanica Slovaca. ISSN 1335-2393. Vol 16/1. 2012. p.30-40

[9] MLECZKO, J. - MIČIETA, B. - DULINA, Ĺ. 2013. Identification of bottlenecks in the unit made to order production. In: Applied Computer Science Vol. 9, No. 2 (2013), p. 43-56. Lublin, Lublin University of Technology. Institute of Technological

[10] KOVÁČ, J. - RUDY, V. - KOVÁČ, J. (2008). Tvorba 3D modelov výrobných systémov a zaskupení. In: Transfer inovácií. - ISSN 1337-7094. - Č. 11 (2008), s. 261-264. 